\title{
Preparing nurses as leaders: How far have we come? / Former les infirmières au leadership : où en sommes- nous?
}

Jacinthe I. Pepin

Université de Montréal, jacinthe.pepin@umontreal.ca

Florence Myrick

amyrick@ualberta.ca

Follow this and additional works at: https://qane-afi.casn.ca/journal

Part of the Educational Leadership Commons

\section{Recommended Citation}

Pepin, Jacinthe I. and Myrick, Florence (2016) "Preparing nurses as leaders: How far have we come? / Former les infirmières au leadership : où en sommes-nous?," Quality Advancement in Nursing Education - Avancées en formation infirmière: Vol. 2: Iss. 2, Article 1.

DOI: https://doi.org/10.17483/2368-6669.1105

This Editorial is brought to you for free and open access by Quality Advancement in Nursing Education - Avancées en formation infirmière. It has been accepted for inclusion in Quality Advancement in Nursing Education - Avancées en formation infirmière by an authorized editor of Quality Advancement in Nursing Education - Avancées en formation infirmière. 


\section{Preparing nurses as leaders: How far have we come?}

In 2010, two reports called for all nurses to be prepared as leaders: 1) The International Commission, Health Professionals for a New Century: Transforming Education to Strengthen Health Systems in an Interdependent World; and 2) The Institute of Medicine, The Future of Nursing: Leading Change, Advancing Health. In each report, patient safety, quality care, and advancement of health systems were the impetus for the call to leadership development by all professionals in medicine, nursing, and public health. Six years later, one may wonder how far we have evolved in nursing education, nursing practice, and nursing policy towards generating environments that actually foster the development of nurses as leaders. In nursing education, we must ask the question, how far have we evolved in the integration of the Canadian Association of Schools of Nursing (CASN, 2015) education guiding principles for the domain of leadership in our baccalaureate, master's, and doctoral nursing programs? In nursing practice and policy, we must also ask how far have we evolved in using best practices for developing and sustaining nursing leadership, such as those published by the Registered Nurses' Association of Ontario (2013).

We suggest that the strengthening of the inter-spheres (education, practice and policy), collaboration, and student partnership hold the potential to propel the development of all nurses as leaders a step further. First, collaboration between the education and clinical/community practice spheres in leadership competency development is obvious through the clinical practicum wherein preceptors, among other roles, espouse a clinical leadership role. Many other inter-sphere initiatives also exist. Less obvious, however, is reaching a consensus among the three nursing spheres with regard to the need to prepare all nurses to exercise leadership for the benefit of the populations' health, as well as the shared responsibility of these spheres. Some may remember the 2011 CASN Graduate Studies Forum debate regarding doctoral programs. A definitive moment for us was the exchange between a policy maker and an education leader on whether or not $\mathrm{PhD}$ programs prepare graduates to exercise leadership in such a way that they can interact with policy makers. Developing leadership at all levels is as important as developing all other competencies if nurses are to effectively engage in shared decision making for the ongoing evolution of the health care system. Indeed, it was through such an approach that the Royal College of Physicians and Surgeons of Canada (2015) responded to the same call from the reports by recently renaming the leadership role in the CanMEDS.

Dr. Deborah Tamlyn, who was interviewed for this edition of $Q A N E / A F I$, is among the scholars who insist on the "need to focus so much more on the people who are actively contributing to achieving the mission, but who do not themselves necessarily hold those positions," and among these people are the students. Beyond developing a student-centered learning environment, do we authentically engage students as partners in creating these learning environments in education, practice, and policy spheres? How would such a partnership contribute in the students' leadership development? Finally, if leadership is a central competency, as we purport to espouse, how do we assess and certify that the students have developed this competency throughout their degree program and therefore have successfully completed the program? And, how do we expect this central competency to be enacted in nursing practice? If we do not address these 
questions, the next generations of nurses might or might not demonstrate leadership for patient safety, quality care, and the advancement of health systems.

In this edition of $Q A N E / A F I$, the publications vary from exploring the work environment of pre-tenure and newly tenured nursing faculty, to examining the integration of a grand theory into nursing practice, and to discerning success of Indigenous health students in community-based programs. Learning to write scholarly and reflective papers, to reflect on cultural diversity, and to prepare for the entry-topractice exam are the topics of the other inspiring articles in this edition. We extend our sincere appreciation to all of the authors and reviewers for engaging in scholarship for quality advancement in nursing education.

\section{Former les infirmières au leadership : où en sommes-nous?}

Deux rapports publiés en 2010 suggèrent que toutes les infirmières soient formées au leadership : 1) The International Commission, Health Professionals for a New Century: Transforming Education to Strengthen Health Systems in an Interdependent World; et 2) The Institute of Medicine, The Future of Nursing: Leading Change, Advancing Health. Dans chacun de ces rapports, la sécurité des patients, la qualité des soins et l'amélioration des systèmes de santé sous-tendent la promotion du développement du leadership chez tous les professionnels de la médecine, des sciences infirmières et de la santé publique. Six ans plus tard, nous pouvons nous demander quels progrès ont été faits en sciences infirmières au niveau de la formation, de la pratique et des politiques quant à la création d'environnements qui favorisent le développement des infirmières en tant que leaders. Dans les milieux de formation infirmière, il importe de nous demander où nous en sommes quant à l'intégration des principes directeurs du Cadre national de l'ACESI (Association canadienne des écoles de sciences infirmières, 2015) pour le domaine du leadership, au sein de nos programmes de baccalauréat, de maîtrise et de doctorat en sciences infirmières. Dans les milieux de pratiques et de politiques en sciences infirmières, nous devons nous demander où nous en sommes en ce qui concerne l'utilisation des meilleures pratiques de développement et de maintien du leadership, telles que celles publiées par l'Association des infirmières et infirmiers autorisés de l'Ontario (2013).

Nous sommes d'avis que le renforcement de la collaboration entre les différentes sphères d'exercice infirmier (formation, pratique et politiques) de même que le partenariat avec les étudiants pourraient propulser le développement de l'ensemble des infirmières en tant que leaders. D'abord, la collaboration entre les sphères de formation et de pratique clinique/ communautaire pour le développement de la compétence de leadership est illustrée lors des stages, où les précepteurs démontrent, entre autres, un rôle de leader clinique. Il existe plusieurs autres initiatives de collaboration entre les différentes sphères. Ce qui est moins facile, par contre, est d'arriver à un consensus au sein des trois sphères des sciences infirmières quant à la nécessité de préparer l'ensemble des infirmières à exercer du leadership au profit de la santé de la population, et quant à la responsabilité de chacune des sphères en ce sens. Certaines se rappellent peut-être du débat sur les programmes de doctorat qui a eu lieu dans le cadre du Forum de l'ACÉSI sur les études supérieures en 2011. Un moment charnière pour nous a été l'échange entre 
une responsable de politiques et une leader en éducation sur la préparation au doctorat de diplômées qui exercent du leadership allant jusqu'à interagir avec des responsables de politiques. Le développement du leadership à tous les cycles universitaires est aussi critique que le développement des autres compétences si les infirmières veulent être en mesure de s'engager dans des prises de décisions partagées pour assurer la transformation continue du système de santé. C'est grâce à une telle approche que le Collège royal des médecins et chirurgiens du Canada (2015) a répondu au même appel provenant des rapports de 2010 en renommant le rôle de leader dans le référentiel CanMEDS.

$\mathrm{D}^{\mathrm{re}}$ Deborah Tamlyn, qui a été interviewée pour cette édition de QANE/AFI, fait partie des universitaires qui soutiennent que «nous devons davantage nous centrer sur les personnes qui contribuent activement à la réussite de la mission [d'une organisation] sans occuper un poste qui le requiert »; parmi ces personnes se trouvent les étudiantes. En plus de développer un environnement d'apprentissage centré sur les étudiantes, les invitons-nous en tant que partenaires véritables dans la création d'environnements d'apprentissage pour les sphères formation, pratique et politique? De quelle façon un tel partenariat pourrait-il contribuer au développement du leadership chez les étudiantes? Finalement, si le leadership est une compétence centrale, tel que nous le prétendons, comment l'évaluer, certifier que les étudiantes ont développé cette compétence pendant leurs études, et donc ont complété le programme avec succès? Et, comment croyons-nous que cette compétence pourra se refléter dans les milieux de pratique? À défaut de répondre à ces questions, les prochaines générations d'infirmières pourraient ou pourraient ne pas faire preuve de leadership au regard de la sécurité des patients, de la qualité des soins et de l'amélioration du système de santé.

Les articles publiés dans cette édition de QANE/AFI varient d'une exploration de l'environnement de travail des professeurs se préparant à l'agrégation ou étant nouvellement agrégés (Singh et al.) à une évaluation de l'intégration d'une théorie à large spectre à la pratique d'infirmières (Tapp et al.), et incluant une analyse de ce qui est reconnu comme étant le succès pour des étudiantes d'origine autochtone inscrites dans des programmes fondés sur la santé de leur communauté (Harder et al.). Les autres articles de cette édition, aussi inspirants, touchent l'apprentissage de la rédaction de textes scientifiques et de textes de réflexion (Chaudoir et al.); de la réflexion sur la diversité culturelle (Huard et al.); et de la préparation à l'examen pour l'exercice de la profession (Cobbett et al.). Nous désirons souligner notre reconnaissance sincère à toutes les auteures et réviseures qui s'engagent dans la recherche visant des avancées en formation infirmière.

Cordialement / Respectfully,

Corédactrices en chef, Co-Editors-in-Chief,

Jacinthe Pepin, inf. Ph. D., Faculté des sciences infirmières, Université de Montréal

Florence Myrick, RN, Ph. D., Faculty of Nursing, University of Alberta 


\section{References / Références}

CASN. (2015). National Nursing Education Framework. Ottawa: Author.

Frenk, J., et al. (2010). Health professionals for a new century: transforming education to strengthen health systems in an interdependent world. Lancet, 376(9756), 192358. http://dx.doi.org/10.1016/s0140-6736(10)61854-5

Institute of Medicine. (2010). The Future of Nursing: Leading Change, Advancing Health. Washington, D.C.: National Academies Institute of Medicine.

Registered Nurses' Association of Ontario. (2013). Developing and Sustaining Nursing Leadership (2nd ed.). Toronto, ON: Registered Nurses' Association of Ontario. This work is funded by the Ontario Ministry of Health and Long-Term Care. 